\title{
Analisis dan Sinkronisasi Tabel Komposisi Pangan Aplikasi Nutrisurvey Versi Indonesia
}

\section{Priyo Sulistiyono ${ }^{1}$,Yanto Heriyanto ${ }^{2}$, Irfan Priyadi ${ }^{3}$, Lisiana Fazriyani Putri ${ }^{4}$, Oetika Rilkiyanti ${ }^{5}$}

1Jurusan Gizi Poltekkes Kemenkes Tasikmalaya, sbimbom@yahoo.com

${ }^{2}$ Jurusan Keperawatan Poltekkes Kemenkes Tasikmalaya

3,4,5Program Studi Gizi Cirebon, Poltekkes Kemenkes Tasikmalaya

Kata kunci:
Ahli Gizi
Aplikasi
Nutrisurvey
Pangan
TKPI

ABSTRAK

Latar Belakang: Ahli gizi Indonesia masih banyak yang menggunakan aplikasi Nutrisurvey (NS) untuk menganalisis kandungan gizi pada bahan makanan dan resep makanan. Nutrisurvey Indonesia (2005) memiliki kekurangan berupa database nilai gizi pangan atau Food Composition Table (FCT) yang masih belum diperbaharui atau disinkronkan dengan Tabel Komposisi Pangan Indonesia (TKPI-2017). Hal ini menyebabkan terjadi ketidaksesuaian perhitungan estimasi nilai gizi pangan. Tujuan: mengetahui perbedaan; jenis pangan, jumlah zat gizi dan nilai gizi pangan pada aplikasi Nutrisurvey (NS-2005) dan TKPI-2017 dan melakukan pembaharuan pangkalan data NS. Metode: Jenis penelitian adalah deskriptif observasional, dengan menyelia perbedaan jenis pangan, jumlah zat gizi dan nilai gizi pangan. Pembaharuan pangkalan data aplikasi NS. Hasil: Jumlah jenis pangan di TKPI sebanyak 1.113 jenis dan Nutrisurvey sebanyak 934 jenis. Nutrisurvey sebanyak 43 zat gizi dan TKPI sebanyak 21 zat gizi. Perbedaan jumlah zat gizi pada keduanya sebesar 22 zat gizi. Nutrisurvey memiliki rerata nilai gizi pangan lebih tinggi daripada TKPI sebesar $34,3 \%$. Hasil sinkronisasi menghasilkan Aplikasi Nutrisurvey dengan pangkalan data baru yang disebut Nutrisurvey-TKPI 2017 (NS-TKPI 2017). Kesimpulan: Nutrisurvey-TKPI 2017 dengan berbagai kelebihannya masih layak untuk digunakan oleh ahli gizi dan praktisi gizi. Nutrisurvey memiliki fitur yang cukup mendukung kerja ahli gizi.

\footnotetext{
Key word:

Nutritionist

Application

Background: Many Indonesian Nutritionists still use the Nutrisurvey (NS) application to

Nutrisurvey analyze the nutritional content of food ingredients and food recipes. Nutrisurvey Indonesia (2005) has a deficiency in the form of a Food Composition Table (FCT) which has not been

Food

TKPI updated or synchronized with the Indonesian Food Composition Table (TKPI-2017). This causes a mismatch in the calculation of the estimated nutritional value of food. Objective: Knowing the differences; the number of food types, types, and nutritional value of food in Nutrisurvey (NS-2005) application and TKPI-2017 data and updating the NS database. Methods: This type of research is observational descriptive, by examining the differences in types of food, amount of nutrients, and nutritional value of food. Updates to the NS application database. Results: The number of types of food in TKPI was 1.113 types and 934 types in Nutrisurvey data. Nutrisurvey with 43 nutrients and TKPI for 21 nutrients. The difference in number of nutrients in both of them is 22 nutrients. Nutrisurvey has a food nutritional value average higher than TKPI of $34.3 \%$. The synchronization results in Nutrisurvey Application with a new database called Nutrisurvey-TKPI 2017 (NS-TKPI 2017). Conclusion: Nutrisurvey-TKPI 2017 with its various advantages is still suitable for use by nutritionists and nutrition practitioners. Nutrisurvey has sufficient features to support the work of nutritionists
}

This is an open access article under the CC-BY-SA license 


\section{Pendahuluan}

Food Composition Table (FCT) atau Tabel Komposisi Pangan, merupakan sebuah pangkalan data pangan yang dimiliki oleh sebuah negara.[1] Tabel komposisi pangan negara dapat menjadi salah satu tolok ukur kemajuan ilmu gizi negara tersebut.

Indonesia memiliki Tabel Komposisi Pangan Indonesia (TKPI) bahkan lebih dari satu, namun belum satupun ditetapkan secara resmi sebagai FCT rujukan resmi yang diakui negara. FCT terbitan terakhir yaitu tahun 2009, yang disusun Persatuan Ahli gizi Indonesia (PERSAGI) dan diterbitkan oleh PT Gramedia Pustaka Utama dengan judul Tabel Komposisi Pangan Indonesia (TKPI).[2] TKPI (2009) masih banyak kekurangan. Upaya perbaikan dan penyempurnaan telah dilakukan oleh Tim Reviu terus dilakukan hingga Januari 2017 melalui metode "Borrowing" yaitu penambahan jenis bahan makanan dan pemberian nama makanan disertai deskripsinya dengan meminjam dari berbagai sumber data.[3]

Penyempurnaan TKPI dan penetapan secara resmi oleh pihak yang berwenang menjadi sangat perlu karena harapannya hanya ada satu TKPI yang dijadikan rujukan oleh seluruh komponen bangsa. Pada tanggal 25 Januari 2017 lahirlah Tabel Komposisi Pangan Indonesia yang baru selanjutnya disebut TKPI 2017.[3]

Program Nutrisurvey (NS) adalah piranti lunak yang bebas pakai untuk keperluan non komersial (only for non commercial use).[4] Ahli gizi banyak menggunakan program NS untuk menganalisis kandungan gizi pada bahan makanan dan atau resep makanan. Nutrisurvey versi Indonesia (2005) memiliki kekurangan berupa database nilai gizi pangan atau Food Composition Table (FCT) yang masih banyak ketidaksesuaian dengan Tabel Komposisi Pangan Indonesia (TKPI-2017).

Nutrisurvey masih banyak digunakan untuk mempercepat penilaian estimasi nilai gizi makanan atau resep makanan, menentukan kebutuhan zat gizi berdasarkan umur, jenis kelamin dan aktivitas fisik, menentukan status gizi berdasarkan umur dan jenis kelamin, menyusun kuesioner survei gizi.[5][6] Program Nutrisurvey banyak ditemukan di berbagai jurnal itu menunjukan nutrisurvey masih banyak digunakan.[7][10] Nutrisurvey memiliki keunggulan dari piranti lain adalah dapat menghitung intake gizi individu atau kelompok, dapat mengolah nilai gizi makanan hasil recall 24 jam dan food frequency questionery, memiliki lembar kerja yang mudah digunakan dan beberapa kelebihan lain.[6]

Nutrisurvey versi Indonesia terakhir diperbaharui tahun 2005, oleh Dr. J. Erhardt bekerjasama dengan Universitas Indonesia-SEAMEO TROPMED dengan editor Usman, DCN (Poltekkes Kemenkes Padang), sehingga belum ada kesesuaian dengan TKPI (2017) yang saat ini banyak digunakan. Nutrisurvey versi ini juga yang tercatat di laman FAO.[1][11]

Hasil studi pendahuluan pada 100 jenis pangan yang dada di Nutrisurvey, diambil acak dari seluruh golongan bahan pangan dan/hasil olahnya. Hasilnya $80 \%$ jenis pangan yang berbeda dan 35\% memiliki nilai gizinya yang berbeda dengan TKPI (2017). Nutrisurvey memiliki pangkalan data yang tidak sesuai dengan TKPI (2017).[12]

Perbedaan tersebut akan berakibat pada ketidaktepatan estimasi nilai gizi pangan, maka perlu dilakukan penelitian analisis pada seluruh data dan melakukan sinkronisasi data pangan pada Nutrisurvey dan Tabel Komposisi pangan Indonesia (TKPI-2017).

\section{Metode}

Jenis penelitian adalah penelitian observasional deskriptif yaitu pengamatan terhadap entitas apa pun yang disajikan dengan nilai numerik.[13] Penelitian ini adalah penelitian dengan menyelia pakalan data pangan pada Nutrisurvey dan TKPI. Penelitian dilakukan Juli-September 2018 di Laboratorium Pangan Prodi Gizi Cirebon Poltekkes Tasikmalaya. Populasi data yang diselia adalah seluruh data pangan Nutrisurvey dan TKPI. Pengumpulan data dilakukan 
dengan menyelia. Nutrisurvey yang digunakan adalah Nutrisurvey 2005 versi Bahasa Indonesia, yang selanjutnya disebut Nutrisurvey. Tabel Komposisi Pangan Indonesia (TKPI) yang gunakan adalah TKPI Tahun 2017, selanjutnya disebut TKPI. Komponen yang diselia adalah jumlah jenis pangan, jumlah jenis zat gizi dan nilai gizi pangan. Analisis data dilakukan secara deskriptif. Tahap akhir penelitian adalah sinkronisasi pangkalan data Nutrisurvey mengacu pada TKPI.

\section{Hasil dan Pembahasan}

\subsection{Jumlah Jenis Pangan}

Hasil penyeliaan menunjukan terdapat perbedaan jumlah jenis pangan yang terdapat pada Nutrisurvey dengan TKPI, mencapai 453 jenis pangan yang berbeda.

Tabel 1. Perbedaan Jumlah Jenis Pangan menurut Kelompok Pangan pada Nutrisurvey dan TKPI

\begin{tabular}{lccc}
\hline \multirow{2}{*}{ Kelompok Pangan } & \multicolumn{2}{c}{ Jumlah Pangan } & $\begin{array}{c}\text { Jumlah } \\
\text { Perbedaan }\end{array}$ \\
\cline { 2 - 3 } & Nutrisurvey & TKPI & 93 \\
\hline $\begin{array}{l}\text { Serealia dan hasil olahannya } \\
\text { Umbi - umbian dan hasil }\end{array}$ & 225 & 132 & 48 \\
olahannya & 39 & 87 & 100 \\
$\begin{array}{l}\text { Kacang - kacangan dan hasil } \\
\text { olahannya }\end{array}$ & 46 & 146 & 2 \\
Lemak dan hasil olahannya & 15 & 13 & \\
$\begin{array}{l}\text { Sayur - sayuran dan hasil } \\
\text { olahannya }\end{array}$ & 136 & & 91 \\
$\begin{array}{l}\text { Buah - buahan dan hasil } \\
\text { olahannya }\end{array}$ & 120 & 227 & 1 \\
Bumbu- bumbu & 36 & 119 & 1 \\
$\begin{array}{l}\text { Daging dan hasil olahnya } \\
\text { Ikan dan hasil olahnya }\end{array}$ & 98 & 37 & 22 \\
Susu dan hasil olahnya & 121 & 120 & 54 \\
Telur dan hasil olahnya & 43 & 175 & 26 \\
Gula dan hasil olahnya & 23 & 22 & 14 \\
\hline \multicolumn{1}{c}{ Total } & 32 & 18 & $\mathbf{4 5 3}$ \\
\hline
\end{tabular}

Jumlah jenis pangan di TKPI sebanyak 1.113 jenis pangan, lebih banyak dibandingkan data Nutrisurvey sebanyak 934 jenis pangan. Kelompok kacang -kacangan dan hasil olahannya, memiliki perbedaan yang paling tinggi sebesar 100 jenis pangan. Jumlah jenis pangan pada kelompok pangan serealia/hasil olahnya, dan susu/hasil olahnya justru Nutrisurvey memiliki jumlah jenis pangannya lebih banyak. Hal tersebut terjadi karena pangkalan data NS versi Indonesia belum mengalami perubahan sejak tahun 2005 yang diterjemahkan oleh Usman Sikumbang dari Jurusan Gizi Politeknik Kesehatan Kemenkes Padang. NS versi Indonesia masih menggunakan pangkalan data DKBM Indonesia.[11]

Indonesia saat ini menggunakan Tabel Komposisi Pangan Indonesia (TKPI) tahun 2017.[3] Ahli gizi pengguna Nutrisurvey perlu menambahkan sendiri sejumlah jenis pangan untuk melengkapi jenis pangan tertentu sesuai TKPI.[14] 


\subsection{Jumlah Zat Gizi}

Perbedaan jumlah zat gizi diukur berdasarkan banyaknya jumlah zat gizi per kelompok bahan makanan dalam Nutrisurvey maupun TKPI. Pengukuran dilakukan dengan cara menyelia. Hasil penyeliaan menunjukkan jumlah zat gizi yang terdapat pada Nutrisurvey sebanyak 43 zat gizi dan TKPI sebanyak 21 zat gizi. Perbedaan jumlah zat gizi pada keduanya sebesar 22 zat gizi. Jumlah jenis zat gizi yang tercantum di TKPI seperti di banyak negara ASIA lainnya, seperti ASEAN Food Composition Table.[15]

Nutrisurvey memiliki zat gizi yang lebih lengkap terutama zat gizi mikro, tetapi masih ada zat gizi yang tidak terdapat pada Nutrisurvey namun terdapat pada TKPI yaitu Air, Abu, dan $\beta$. Karoten.[3] Negara maju seperti negara eropa memiliki FCT yang jauh lebih lengkap terutama nilai gizi mikro, seperti jenis asam amino, asam lemak dan yang lainnya.[16]

TKPI sebagai pangkalan data zat gizi pangan nasional tentu perlu memuat lebih banyak zat gizi mikro. Zat gizi mikro dalam pangan ini perlu karena seiring perkembangan masalah gizi yang timbul akibat kekurangan atau kelebihan zat mikro tertentu. Negaranegara maju seperti negara eropa jenis zat gizi pangan tersedia lebih lengkap seperti jenisjenis asam amino, jenis lemak.

\subsection{Nilai Gizi Pangan}

Hasil penyeliaan nilai gizi pangan, sebagai ilustrasi berikut adalah hasil analisis nilai gizi lima jenis pangan menggunakan Nutrisurvey dan TKPI.

Tabel 2. Perbedaan Nilai Gizi Pangan per $100 \mathrm{~g}$ pada Nutrisurvey dan TKPI

\begin{tabular}{lcccccc}
\hline \multirow{2}{*}{$\begin{array}{c}\text { Bahan } \\
\text { Makanan }\end{array}$} & \multicolumn{2}{c}{ Energi (kkal) } & \multicolumn{2}{c}{ Protein $(\mathrm{g})$} & \multicolumn{2}{c}{ Lemak (g) } \\
\cline { 2 - 7 } & NS 2005 & Buku & & Buku & & Buku \\
& & TKPI & NS 2005 & TKPI & NS 2005 & TKPI \\
& 2017 & & 2017 & & 2017 \\
\hline Nasi & 130,0 & 179,7 & 2,9 & 3,0 & 0,2 & 0,3 \\
Ayam & 284,9 & 297,8 & 26,9 & 18,2 & 18,9 & 25,0 \\
Telur & 155,1 & 153,9 & 12,6 & 12,4 & 10,6 & 10,8 \\
Jeruk & 47,1 & 44,9 & 0,9 & 0,9 & 0,1 & 0,2 \\
Bayam & 37,0 & 16,0 & 3,7 & 0,9 & 0,2 & 0,4 \\
\hline Jumlah & 654,2 & 692,4 & 46,5 & 35,4 & 30,0 & 36,7 \\
\hline
\end{tabular}

Tabel 2. menunjukan bahwa hasil analisis nilai gizi pada lima jenis pangan menghasil estimasi nilai gizi energi, protein dan lemak yang berbeda. Peneliti juga mengambil 62 bahan pangan secara acak mencakup semua kelompok pangan. Nilai gizi yang didapat pada bahan pangan yang sama dihitung selisih perbedaannya, kemudian selisih dihitung ratarata pada masing- masing zat gizi di tiap kelompok pangan. Hasilnya menunjukan bahwa Nutrisurvey memiliki nilai gizi lebih tinggi daripada TKPI sebesar 34,3\%. Kualitas data kandungan gizi berbagai jenis pangan dipengaruhi oleh banyak faktor. Varietas jenis bahan pangan, kadar air bahan, tempat/daerah dimana tanaman atau hewan tersebut hidup dan lainnya. [17][18][20] Kualitas dan ketersediaan data nilai gizi berbagai jenis pangan juga sangat dipengaruhi kemampuan suatu negara untuk melakukan analisis nilai gizi pangan.[2] Banyaknya jenis pangan dan jenis zat gizi yang harus dianalisis menjadi faktor besar biaya analisis zat gizi pangan. Untuk itu sebagian nilai gizi pangan yang ada di TKPI didapat dari meminjam (borrowing) dari FCT negara lain yang secara geografis hampir sama dengan Indonesia.[21] 
Ahli gizi tidak disaran menggunakan Aplikasi Nutrisurvey (2005) versi Indonesia untuk menghitung estimasi nilai gizi pangan atau resep pangan. Hasil estimasi nilai gizi pangan menunjukan nilai gizi yang lebih tinggi, jika menggunakan Aplikasi Nutrisurvey versi Indonesia.

\subsection{Sinkronisasi Pangkalan Data Nutrisurvey}

Aplikasi Nutrisurvey memiliki beberapa keunggulan, diantaranya berbasis windows yang mudah digunakan (user friendly), Aplikasi kompatibel di semua sistem windows, freeware dan Open Source dan WHO telah mengakuisisi Nutrisurvey sebagai bagian dari program official WHO-antro 2005 (versi Beta).[22] Ahli gizi di Indonesia banyak menggunakan aplikasi Nutrisurvey dalam mengestimasi nilai gizi pangan.[5]

Pangkalan data Nutrisurvey perlu diperbaharui disesuaikan dengan TKPI. Pangkalan data Sebagai acuan adalah kandungan gizi yang tertuang dalam Buku Tabel Komposisi Pangan Indonesia (TKPI) yang diterbitkan oleh Direktorat Gizi Kementerian Kesehatan Indonesia Tahun 2017. Proses sinkronisasi didahului dengan permintaan izin Dr. Juergen Erhardt selaku pemilik piranti lunak Nutrisurvey.[23] Izin Direktur Gizi Masyarakat Kementerian Kesehatan RI selaku lembaga penanggung jawab penerbitan. Buku TKPI digunakan sebagai acuan standar jumlah dan jenis pangan/zat gizi serta nilai gizi pangan.

Sinkronisasi dilakukan dengan mengganti pangkalan data Nutrisurvey dengan pangkalan data TKPI 2017. Aplikasi Nutrisurvey yang sudah diperbarui disebut NS-TKPI 2017. Aplikasi ini menghasilkan estimasi kandungan zat gizi pangan yang sama dengan TKPI 2017, jadi lebih memudahkan dan mempercepat kerja ahli gizi dibandingkan dengan manual menggunakan Buku TKPI. Kelebihan lain adalah pengguna dapat memperbarui pangkalan data NS-TKPI 2017 mengikuti pembaharuan TKPI secara berkala. Gambar 1 adalah ilustrasi hasil estimasi kandungan zat gizi menggunakan NS-TKPI 2017.

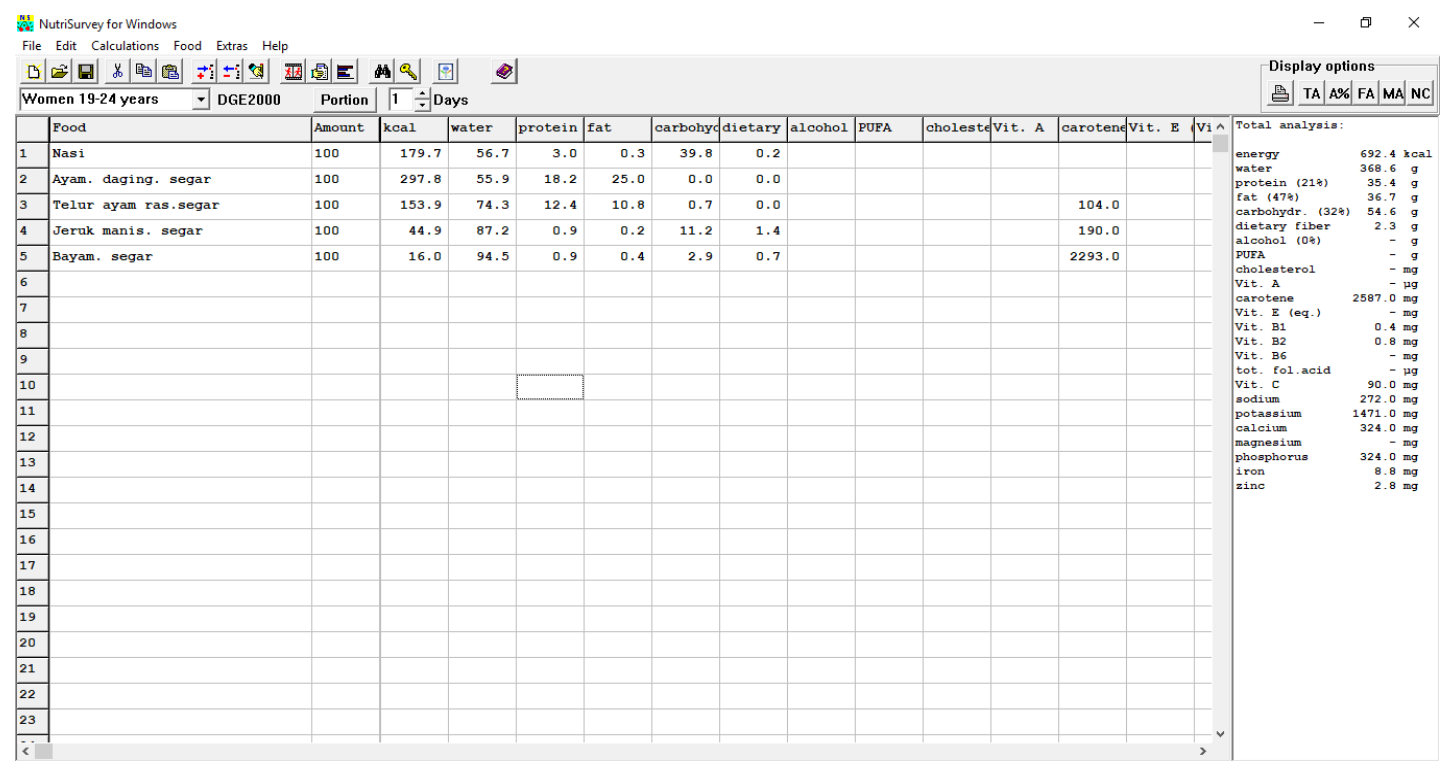

Gambar 1.

Hasil Analisis Nilai Gizi Pangan menggunakan Aplikasi NS-TKPI 2017

Nutrisurvey-TKPI 2017 dengan berbagai kelebihannya masih layak untuk digunakan oleh ahli gizi dan praktisi gizi.[24] Nutrisurvey memiliki fitur yang cukup mendukung kerja ahli gizi.[10] 


\section{Kesimpulan}

Jumlah jenis pangan di TKPI sebanyak 1.113 jenis pangan, lebih banyak dibandingkan data Nutrisurvey sebanyak 934 jenis pangan. Nutrisurvey sebanyak 43 zat gizi dan TKPI sebanyak 21 zat gizi. Perbedaan jumlah zat gizi pada keduanya sebesar 22 zat gizi. Nutrisurvey memiliki rerata nilai gizi pangan lebih tinggi daripada TKPI sebesar 34,3\%. Hasil sinkronisasi menghasilkan Aplikasi Nutrisurvey dengan pangkalan data baru yang disebut NutrisurveyTKPI 2017 (NS-TKPI 2017). Nutrisurvey-TKPI 2017 dengan berbagai kelebihannya masih layak untuk digunakan oleh ahli gizi dan praktisi gizi. Nutrisurvey memiliki fitur yang cukup mendukung kerja ahli gizi.

\section{Ucapan Terima Kasih}

Ucapan terima kasih pada Dr. Juergen Erhardt selaku pemilik piranti lunak Nutrisurvey yang telah memberikan izin dan juga membantu proses sinkronisasi database Nutrisurvey 2017 versi Indonesia. Terima Kasih kepada Direktur Gizi Masyarakat Kementerian Kesehatan RI selaku lembaga penanggung jawab TKPI di Indonesia yang secara tertulis telah memberikan izin pengunaan data TKPI 2017 untuk digunakan pada Nutrisurvey. Ucapan terimakasih juga penulis sampaikan pada Kepala PPSDM Kesehatan dan Direktur Poltekkes Kemenkes RI yang telah memberikan dukungan pembiayaan penelitian ini.

\section{Referensi}

[1]. FAO. International Food Composition Table. http://www.fao.org/infoods/infoods/tablesand-databases/en/ (accessed 26 September 2017)

[2]. Mahmud MK. Tabel Komposisi pangan Indonesia (TKPI). 5th ed. Jakarta: Gramedia, 2015.

[3]. Kementerian Kesehatan RI. Updating Tabel Komposisi Pangan Indonesia, http://gizi.depkes.go.id/wp-content/.../2017/.../UpdatingTKPI\%257B_\%257DHGN\%257B_\%257D250117\%257B_\%257DFinal-GAIN. (2017).

[4]. Juergen Erhardt. Description of NutriSurvey, http://www.nutrisurvey.de/index.html (2010, accessed 14 April 2018).

[5]. Bardosono S. Pelatihan menggunakan program NutriSurvey secara praktis, http://staff.ui.ac.id (2010, accessed 26 September 2017).

[6]. Sulistyono P. Buku Penuntun Praktikum Komputer Lanjut. 1st ed. Cirebon: Prodi DIII Gizi Cirebon Poltekkes Kemenkes Tasikmalaya, 2014.

[7]. Jati, I. R. A., Widmer, C., Purwestri, R. C., Wirawan, N. N., Gola, U., Lambert, C., \& Biesalski HK. Design and validation of a program to identify inadequate intake of iron, zinc, and vitamin A. Nutr , 2014; 30 (11-12): 1310-1317.

[8]. Kotepui M, Sarakul O, Uthaisar K, et al. Dietary Intake of High School Girls Aged 15-18 Years in Nakhon Si Thammarat Province, Thailand. 2016; 30: 75-82.

[9]. International journal of environmental research and public health, 16(16) 2852. Validation of the CIMI-Ethiopia Program and Seasonal Variation in Maternal Nutrient Intake in Enset (False Banana) Growing Areas of Southern Ethiopia. Int J Environ Res public Health 2019; 2852: 2852.

[10]. Saputra, N. P. K., Lipoeto, N. I., \& Machmud R. Analysis of nutrients and body mass index as risk factors for preeclampsia. J Obstet Gynecol India 2017; 67(6): 409-413.

[11]. Sikumbang U. NutriSurvey Software Pengolah Data Konsumsi, https://bakuldata.blogspot.co.id/2010/10/nutrisurvey-software-pengolah-data.html (2010, accessed 12 September 2017).

[12]. Kementerian Kesehatan RI. Pusat Data dan Informasi Kesehatan, http://www.kemenkes.go.id (2014, accessed 12 September 2017). 
[13]. Sandu Siyoto. Dasar Metodologi Penelitian. Cetakan-1. Yogyakarta: Literasi Media Publishing, 2015.

[14]. Erhardt J. Nutrition Surveys and Calculations, Guidelines and Additional Information, http://www.nutrisurvey.de (2010, accessed 12 September 2017).

[15]. Institute of Nutrition MU. ASEAN Food Composition Database, Electronic version 1. Thailand, http://www.inmu.mahidol.ac.th/aseanfoods/composition_data.html (2014).

[16]. National Food Institute Technical. Food data (frida.fooddata.dk), version 4. University of Denmark, 2019, frida.fooddata.dk (2019).

[17]. Hasmar Fajriana FRM. Analisis Kandungan Gizi Tepung Ikan Penja (Indigenous species) pada Berbagai Metode Pengeringan. J Nutr 2019; 21: 61-66.

[18]. Fristianti VL, Hidayat N, Iskandar S. Kajian Kandungan Fe dalam Air Tanah Terhadap Kadar Ekskresi Yodium dalam Urin pada Anak Sekolah di Desa Cerme Kecamatan Panjatan Kabupaten Kulon Progo. J Nutr 2017; 19: 7-11.

[19]. Meiningtyas A. Kandungan Karbohidrat, Protein, Dan Lemak Pada Makanan Siap Saji Khas Indonesia Yang Dianalisis Dengan Menggunakan Analisis Proksimat Dan Software Nutrisurvey. Dr Diss Univ Brawijaya.

[20]. Muctadi, Tien; Sugiyono; Ayustaningwarno F. Ilmu Pengetahuan Bahan Pangan. 1st ed. Bandung: Alfabeta, 2015.

[21]. Puwastien P. Issues in the development and use of food composition databases. Public Health Nutr 2002; 5: 991-999.

[22]. Kristanto Y. Tiptrik NutriSurvey untuk Menganalisa Kecukupan Gizi Individu dan Kelompok, https://www.slideshare.net/YohanesKristianto2/tip-trik-nutrisurvey-utkmenganalisis-kecukupan-gizi-individu-kelompok (2013, accessed 28 September 2017).

[23]. Erhardt J. Nutrisurvey for Windows, Dietary Analysis Package. Copyright $\subset$ Only non Commercial use, Univ Indonesia SEAMEO-TROPMED.

[24]. Erhardts J. NutriSurvey for Windows Software. University Indonesia SEAMEO TROPMED. 